\title{
TechSights
}

\section{Of Molecules and Mechanisms}

\author{
(DDeanna L. Benson \\ Nash Family Department of Neuroscience and Friedman Brain Institute, Icahn School of Medicine at Mount Sinai, New York, New York 10029
}

Without question, molecular biology drives modern neuroscience. The past 50 years has been nothing short of revolutionary as key findings have moved the field from correlation toward causation. Most obvious are the discoveries and strategies that have been used to build tools for visualizing circuits, measuring activity, and regulating behavior. Less flashy, but arguably as important are the myriad investigations uncovering the actions of single molecules, macromolecular structures, and integrated machines that serve as the basis for constructing cellular and signaling pathways identified in wide-scale gene or RNA studies and for feeding data into informational networks used in systems biology. This review follows the pathways that were opened in neuroscience by major discoveries and set the stage for the next 50 years.

Key words: PCR; RNA; transfection and transduction; SNARE and synapse composition; nanoscale imaging; CRISPR-Cas9

\section{Introduction}

Modern neuroscience rests on the back of molecular biology. Without question, the tools and tactics that have emerged from molecular biology coupled with what has been learned about individual molecules and molecular machines have changed fundamentally the nature of the questions that neuroscientists ask and the perspective from which data are interpreted. Major discoveries in molecular biology have blazed a trail toward advances in neuroscience.

They have generated tools that are used to probe pathways, to identify and classify cell types and states of differentiation, and to illuminate intracellular signaling pathways running from synapses to the nucleus and back. More importantly, a full understanding of the biological function of individual molecules and their role within macromolecular networks has provided the field with essential building blocks of information needed to comprehend the normal function of cells and circuits, as well as to understand how circuits develop, how they are shaped by use or by insult, how they have evolved, and how they behave in the context of disease-causing gene mutations. The function of a surprisingly large body of biologically active gene products in the nervous system is not yet known, but it is significant that use of the word "mechanism" in the literature shows a strong correlation with the appearance of the word "molecule" or "molecular"; $r=0.96$, Journal of Neuroscience PubMed data from 1981 to 2019.

The past 50 years has been something of a golden age for molecular biology (Fig. 1), that was initiated by two DNA-related discoveries. The first is the development of recombinant DNA technology (Jackson et al., 1972; Cohen et al., 1973), in which DNA sequences from two different species are ligated and ex-

Received April 1, 2019; revised Aug. 25, 2019; accepted Aug. 31, 2019.

This work was supported by the NIMH (MH103455, MH104491) and NINDS (NS107512). I thank Dr. Stephen Salton, Dr. George Huntley, and my reviewers for their constructive comments on the paper.

The author declares no competing financial interests.

Correspondence should be addressed to Deanna L. Benson at deanna.benson@mssm.edu.

https://doi.org/10.1523/JNEUROSCI.0743-19.2019

Copyright $\odot 2020$ the authors pressed in a host cell. The second is Sanger DNA sequencing, a method that coupled the incorporation of radiolabeled nucleotides to random chain termination so that after size separation on a gel, the nucleotide code could be read on film. Together, the two techniques enabled molecular cloning, sequencing, and expression of a broad array of novel coding sequences. These discoveries led to the large-scale production of insulin (Goeddel et al., 1979a), somatostatin (Itakura et al., 1977), and human growth hormone (Goeddel et al., 1979b) in bacteria, and coupled with the development of techniques to transfect DNA into eukaryotic cells (Wigler et al., 1977), provided the foundation for the modern biotech industry. It was also appreciated at the time that along with extraordinary opportunity comes the possibility of unknown and unintended consequences, and the discovery of recombinant DNA was also soon followed by the 1975 Asilomar Conference in which researchers, the press, and the public debated and adopted stringent guidelines addressing the manipulation of DNA from different species (Berg et al., 1975). This largely successful effort at self-regulation by scientists has been codified in regulations set out by a variety of international agencies, that along with subsequent guideline-writing conferences (Baltimore et al., 2015), have proven mostly, but not entirely (Wang et al., 2019), successful at setting up guardrails.

The discovery of PCR acted like an accelerant for discovery in the life sciences in the 1980s (Saiki et al., 1985; Mullis et al., 1986), and it is hard to overestimate its practical significance. Its impact on neuroscience was almost immediate because the conceptmultiple rounds of DNA polymerization between two annealed primers-was simple, and its implementation, using an automated thermocycler and a heat-resistant polymerase (Taq), was inexpensive and easy. Expectations grew from a place in which the discovery and sequencing of a single expressed gene constituted an entire $\mathrm{PhD}$ thesis, to one in which a family of structurally or functionally related genes, splice variants, and cellular distribution patterns could be found along with a chapter using experimental manipulations. PCR revolutionized approaches for many laboratories and it changed the course of my own thesis 


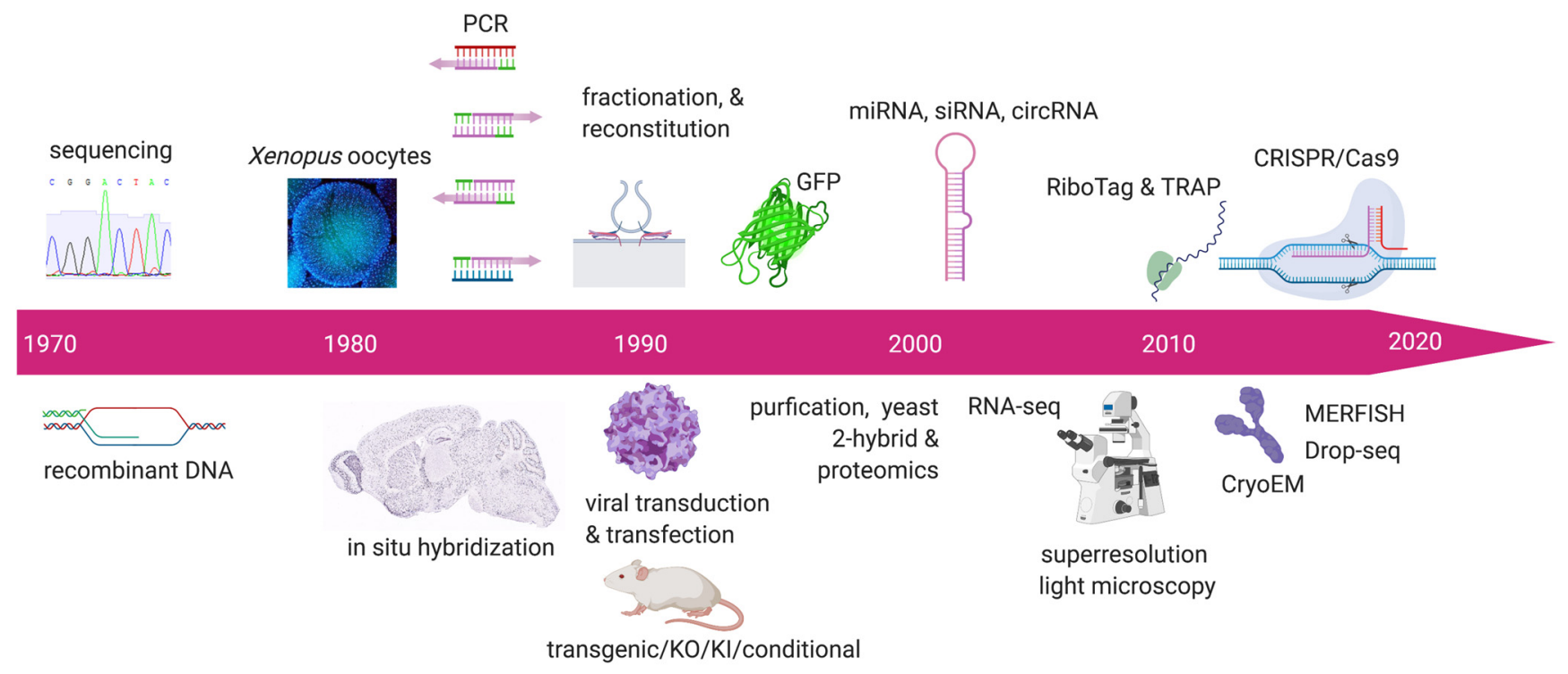

Figure 1. Timeline shows some of the major technical breakthroughs in molecular biology that have driven the field forward over the past 50 years. K0, knock-out; $\mathrm{KI}$, knock-in. Hoechst-stained oocyte image from Vincent Pasque (https://creativecommons.org/licenses/by-nc-nd/2.0/uk/); sagittal section of mouse brain showing Gad1 mRNA distribution from Allen Brain Atlas (Lein et al., 2007). Figure created in BioRender.com.

work. But my experience was not unusual; according to Google Scholar, PCR was featured in 72,000 papers in its first 10 years.

The vast majority of bench-type neuroscience laboratories still use PCR regularly, most commonly for genotyping or for generating plasmid cDNA constructs, but in its first years, before the completion of the Human Genome Project, it was a tool for discovery. The 1980s and early 1990s saw a dramatic increase in the number of novel transcription factors, ion channels, and neuropeptides that were identified. Strategies to identify entirely unknown coding sequences still relied on challenging or iterative methods like chromosome walking in Drosophila or Caenorhabditis elegans (Davis and Davidson, 1984; Finney et al., 1988) or expression cloning (Lechan et al., 1986), but once a sequence was identified, standard PCR methods using degenerate oligonucleotide primers could be used to rapidly identify isoforms, family members, and even distant relatives (Keinänen et al., 1990). The rapid pace of discovery drove the development of approaches that could be used to examine the distribution and function of particular molecules. Two standouts in this arena are in situ hybridization and the use of heterologous cells.

In situ hybridization was first described in 1969 (Pardue and Gall, 1969), but its widespread use awaited PCR and the development of non-isotopic tags in the 1980s. In neuroscience, its use expanded exponentially with the explosion of primary sequence information. As soon as a new coding sequence or a splice variant was identified, RNA and oligonucleotide probes could be easily and cheaply synthesized, and cellular and regional distribution patterns over time or in response to a stimulus could be determined. For example, in situ hybridization experiments revealed that the onset and duration of c-fos, NGF, and BDNF expression following seizure showed regional and cell-type specificity (Morgan et al., 1987; Gall and Isackson, 1989; Isackson et al., 1991); and that the distribution of receptor-subunit mRNAs could be used to predict relevant subunit combinations and changes in function observed over the course of development (Monyer et al., 1994). Particularly noteworthy was the discovery that particular mRNAs were transported into dendrites and axons (Burgin et al., 1990; Benson et al., 1992; Bassell et al., 1998) where their distribution and translation could be regulated by activity, insult, or external cues (Aakalu et al., 2001; Campbell and Holt, 2001; Zheng et al., 2001). Indeed, in situ hybridization using probes specific for nuclear-localized primary transcripts (hnRNA) was used to study rapid regulation of gene transcription in neuroendocrine and neural cells and tissues (Fremeau et al., 1986).

The utility of in situ hybridization has only continued to grow. Baseline distribution patterns for most mRNAs are now publicly available for both developing and adult mouse (GenePaint, Visel et al., 2004; Allen Brain Atlas, Lein et al., 2007), human (Miller et al., 2014), and marmoset brain (Brain/MINDS; Woodward et al., 2018). The Allen Mouse Brain Atlas alone provides data for the localization of $>20,000$ genes and has been cited $>3000$ times. Recent advances have also fueled an expansion of scale. In particular, multiplexing and iterative strategies that use a rainbow of color tags and spectral separation allow examination of the location of several mRNAs in tissue or even within whole animals (Lovett-Barron et al., 2017; Meissner et al., 2019). MERFISH (multiplexed error-robust fluorescence in situ hybridization) is an outstanding example of this strategy, in that it uses a singlemolecule imaging approach to identify thousands of mRNAs in single cells in intact tissue (K. H. Chen et al., 2015; Moffitt et al., 2016). Such in situ studies have also established the framework for current efforts aiming to identify the entire transcriptome of single cells (Macosko et al., 2015).

Knowing what a molecule does is even more important than where it acts, and the creative use of heterologous, reduced preparations has played a significant role in assessing function. For signaling molecules that are broadly expressed, predictions about what they do can be based on known actions in cells outside the nervous system, at least as a starting point. But for the many molecules unique to the nervous system, heterologous preparations have proven to be extremely valuable for identifying and measuring activity. In the wake of PCR, longstanding efforts to identify and characterize the primary structure of ion channels like nicotinic acetylcholine receptors (Giraudat et al., 1982; Noda et al., 1982; Patrick et al., 1983) or sodium channels (Hartshorne and Catterall, 1984; Noda et al., 1986), were overtaken by the need to assign functional attributes and rules of assembly to the ion channel subunits encoded by a growing number of sequences. 
In 1982, Ricardo Miledi and Katumi Sumikawa showed that exogenous mRNAs encoding individual ion channel subunits, when introduced into Xenopus oocytes, were translated and assembled into functional channels, the properties of which could be recorded electrophysiologically (Miledi et al., 1982). The method was simple and was widely adopted to assess basic functional properties, as well as to determine subunit identity and stoichiometry, to identify protein interacting sequences and ligand binding sites, and to evaluate the impact of signaling partners. Two decades later, a different heterologous strategy was taken to screen and evaluate properties of cell adhesion proteins capable of promoting the generation of synapses. In its first iteration, Scheiffele et al. (2000) tested whether synapse-like junctions would form between presynaptic axons growing from a pontine explant across HEK cells expressing candidate postsynaptic synaptogenic proteins. This basic assay established canonical properties of molecules promoting synaptogenesis and it and its variants have helped to identify most of the adhesion proteins known to occupy the synaptic cleft (Biederer et al., 2002; Seabold et al., 2008; Woo et al., 2009; Siddiqui et al., 2010). These are just two examples among many that demonstrate the usefulness of heterologous preparations for establishing the nature and limits of molecular function.

Heterologous preparations are not an end. They are ultimately and obviously limited because they may lack a fully relevant signaling environment or express modifying factors that would never be found in homologous cells. However, until the 1990s, it was virtually impossible to introduce nucleotides into neurons outside of whole-animal transgenics, a situation that promoted the successful use of genetically accessible organisms like Drosophila and C. elegans to test molecular function (Doe et al., 1988; Way and Chalfie, 1988) and spurred the development of knockout, knock-in, and conditional approaches that could be used in mice (Doetschman et al., 1987; Thomas and Capecchi, 1987; Tsien et al., 1996). Introducing nucleotides into postmitotic cells remains an ongoing challenge, but several independent strategies emerged over a 10 year period that are still in use. The methods can be categorized into chemical (lipofection: Felgner et al., 1987; calcium phosphate: Xia et al., 1996), physical (injection: Gagliardini et al., 1994; electroporation: Muramatsu et al., 1997; biolistics: Lo, 2001), and viral-mediated transduction (HSV: Geller and Freese, 1990; AAV: Kaplitt et al., 1994; lentivirus: Naldini et al., 1996; Sindbis: Altman-Hamamdzic et al., 1997). All have pros and cons that can be exploited toward particular experimental ends, but AAV, although limited to sequences smaller than $5 \mathrm{~kb}$, has become the gold standard. It works very well in vivo, does not compromise cell health or integrate (usually) into the host genome, and depending on serotype, displays specificity for particular neuron subtypes (Choi et al., 2005; Chan et al., 2017), oligodendrocytes (Powell et al., 2016), or microglia (Cucchiarini et al., 2003; Rosario et al., 2016). Some of the first studies to take advantage of transfection were protein domain swapping experiments that identified protein signatures and pathways used by neurons to target membrane proteins selectively to axons, dendrites, or synapses (Jareb and Banker, 1998; Stowell and Craig, 1999). Such studies typically combined transfection, transduction, or genetic engineering with immunolabeling for a unique exogenous tag, a strategy that was limited mostly to fixed preparations.

The need for better tags was fulfilled by the discovery of green fluorescent protein (GFP). The Chalfie laboratory first illustrated the experimental utility of GFP shortly after its sequencing by expressing it downstream of a $\beta$-tubulin promoter in a small population of sensory neurons in C. elegans. Their data showed that GFP could be used as a reporter for transcriptional activity and also filled the branches of a developing neuron, highlighting its potential for live cell imaging (Chalfie et al., 1994). Within 2 years, GFP was being used as a fusion tag to track protein localization in fixed and living neurons (Moriyoshi et al., 1996), to measure vesicle trafficking and release in living cells, and to report changes in voltage (Siegel and Isacoff, 1997) and signaling activity (Tannahill et al., 1995). The advent of multiple color, unstable, $\mathrm{pH}$-sensitive, $\mathrm{Ca}^{2+}$-sensitive, and photo-switchable variants of GFP and the discovery of related fluorescent proteins (Rodriguez et al., 2017) has provided the field with a series of tools that permit measurements within cells. GFP has pushed the development of optical tools like GCaMP (Nakai et al., 2001), which reports changes in calcium levels as a proxy for activity in coordinated neural networks of awake, behaving animals (Tian et al., 2009), and of FRET-based tools that can detect nanoscale protein-protein interactions (Heim and Tsien, 1996; Mitra et al., 1996). Although most GFP-based reporters are independent markers or fusion proteins expressed episomally or transgenically, recent advances have made possible the generation of knock-in tags in postmitotic cells to track localization of endogenous protein (Nishiyama et al., 2017).

Concurrent with the emergence of advances in protein tagging and expression, some of the most significant research in neuroscience in the 1980s and 1990s emerged from studies using sophisticated biochemical techniques that took advantage of properties unique to synapses. The best example of this is the SNARE hypothesis, which grew out of sophisticated fractionation, isolation, affinity purification, and reconstitution strategies that converged with efforts to dissect the secretory pathway in yeast using genetics. The identification of NSF (N-ethylmaleimide-sensitive fusion protein; Malhotra et al., 1988), VAMP/ synaptobrevin (Trimble et al., 1988; Südhof et al., 1989), SNAPs (NSF attachment proteins; Clary et al., 1990), synaptotagmin (Perin et al., 1991; Brose et al., 1992), and Munc18 (Hata et al., 1993), and their relevance to exocytosis interdigitated with work delineating the role of SEC genes in the secretory pathway in yeast (Kaiser and Schekman, 1990). The mechanism unfolded like a story published in installments from the laboratories of James Rothman, Thomas Südhof, Reinhard Jahn, Richard Scheller, and Randy Schekman. Their findings were joined by the observations that toxins blocking transmitter release (tetanus and botulinum) cleaved VAMP/synaptobrevin, SNAP25, and Syntaxin (Schiavo et al., 1992; Blasi et al., 1993a,b), and together the data provide an elegant demonstration of the importance of identifying the molecules that compose a function, characterizing the individual components, and reconstituting the function in vitro.

The ability to purify biochemically the mostly insoluble material that constitutes glutamatergic postsynaptic densities has also greatly advanced our understanding of the molecular organization of postsynapses. In separate efforts in the late 1990s, Mary Kennedy and Craig Garner identified and characterized PSD95/SAP90 using purified postsynaptic densities as a starting material (Cho et al., 1992; Kistner et al., 1993). Both laboratories noted three repeating $\sim 90$ aa protein domains, which based on similarity to domains in Drosophila discs large and Zonula occludens, were dubbed PDZ domains (Kennedy, 1995). The discovery of PDZ domains snowballed into an elementary understanding of synaptic scaffolds and the rules underlying their organization. They bind to short sequences that are usually at the C-terminus of proteins like Shaker $\mathrm{K}^{+}$channels and GluN2 receptors (Niethammer et al., 1996; Songyang et al., 1997); and in PSD95/SAP90 and the hundreds of other proteins that have been 
identified carrying PDZ domains since, they serve to appropriately localize proteins, to bring signaling partners into close proximity, and as a means to generate an organized synaptic scaffold (Garner et al., 2000; Valtschanoff and Weinberg, 2001). Yeast-2hybrid screening for cytoplasmic protein-protein interactions proved to be an outstanding tool for identifying additional synaptic scaffolding proteins and their interacting partners (Garner et al., 2000; Kim and Sheng, 2004). Advances in liquid chromatography coupled to tandem mass spectrometry supported a series of successful efforts in the early 2000s to identify a generic, glutamatergic PSD proteome (Jordan et al., 2004; Peng et al., 2004; Yoshimura et al., 2004; Phillips et al., 2005). Although PSD function is less well understood than vesicle fusion, recent work using newly developed biochemical approaches based on proximity tagging, are contributing to a new wave of discovery, mapping interprotein relationships and identifying subcellular proteomes (Loh et al., 2016; Spence et al., 2019).

Recent advances in microscopy are also steadily chipping away at the gap in knowledge that lies between the attributes of individual molecules and their actions in cells. Single particle cryo-electron microscopy (cryo-EM), which makes visible molecules and macromolecular structures at subnanometer resolution, has been carving out new territory in ion channel biology (Liao et al., 2013; Fan et al., 2018; Shen et al., 2018; Laverty et al., 2019). For example, a recent analysis of native AMPA receptors isolated from rat brain showed that GluA subunit positioning and overall receptor architecture differed from predictions based on recombinant receptors and further revealed that $\sim$ one-third of the receptors were triheteromers, a composition that is novel (Zhao et al., 2019). Examination of the transsynaptic structure generated by presynaptic $\beta$-neurexin 1 , extracellular cerebellin1, and postsynaptic GluAD at parallel fiber-Purkinje cell synapses not only illustrated the molecular composition and interactions that promote assembly of this synapse, but also revealed the structural alterations in GluAD that are likely to support longterm depression (Elegheert et al., 2016). Such single-particle data are being extended by advances in cryo-electron tomography (cryo-ET), where multiple EM images of unfixed, rapidly frozen cells taken at different angles are assembled into tomograms of a $3 \mathrm{D}$ cellular landscape at a resolution of $\sim 4 \mathrm{~nm}$. The molecular complexes observed in cryo-ET can be difficult to attribute, but an expanding library of single-particle EM data, correlative light EM (CLEM) techniques, and targeted experimental manipulations are permitting the identification of structures as well as the roles played by particular molecules in forming or regulating macromolecular assemblies (Fernández-Busnadiego et al., 2010; Perez de Arce et al., 2015; Vargas et al., 2017; Tao et al., 2018). These EM strategies have been joined by the development of super-resolution light microscopy, which permits the assessment of single, labeled molecules and relationships between molecules within cells, even living cells (Chamma et al., 2016), at resolutions that can approach $10 \mathrm{~nm}$. High-resolution examination of synaptic proteins is revealing a transsynaptic, modular organization (Dani et al., 2010; Perez de Arce et al., 2015; Tang et al., 2016; Biederer et al., 2017; Hruska et al., 2018) that is evident in cryo-ET (Perez de Arce et al., 2015). Expansion microscopy is also proving to be valuable for showing relationships between proteins, or between proteins and RNA (F. Chen et al., 2015; Chozinski et al., 2016; Hafner et al., 2019). Most exciting, though, is the capacity for these high-resolution strategies to reveal novel molecular structures and interactions. A beautiful illustration of this is the actin-rich rings in axons discovered in Xiowei Zhuang's laboratory using a single-molecule, stochastic-labeling approach called STORM. The regularly spaced actin bands are separated from one another by spectrin tetramers (Xu et al., 2013). They are most prominent in axons, evident in some dendrites, and observed in neurons across species from C. elegans to human (He et al., 2016). The existence of this entirely novel scaffold has been verified by other techniques in several laboratories (D'Este et al., 2015; Ganguly et al., 2015) and provides an excellent example of a molecular observation prompting functional questions: What do the rings do? How are they modified to permit the emergence of protrusions or synaptic boutons? Can they counter axonal degeneration?

The early 2000s were led by the discovery that RNA can regulate genes. When Andrew Fire and Craig Mello showed that exogenously introduced double-stranded RNAs produced a dramatic and selective inhibition of protein translation in C. elegans, the impact reverberated across all of biology (Fire et al., 1998). A series of rapid-fire investigations uncovered the endogenous cellular strategies used to generate short interfering RNAs (siRNAs) that destroy mRNA, block translation, or inhibit transcription (Novina and Sharp, 2004). Because siRNAs could be introduced exogenously into identified cells at particular times, siRNA-based experimental approaches fully enabled fast and inexpensive ways to conduct loss-of-function studies that were temporally and spatially controlled. They were used widely and aggressively to identify and dissect the contributions of single molecules and protein motifs to a variety of signaling and cellular pathways in neurons (Bai et al., 2003; Pekarik et al., 2003; Hamilton et al., 2005). However, in mammalian cells, the delivery of siRNAs also provokes cellular defense mechanisms against viruses and activates the interferon pathway (Gantier and Williams, 2007). This and other off-target effects have diminished enthusiasm for its wide-scale use. However, largely in parallel to the discovery of siRNA, it was discovered that microRNAs (miRNAs) are liberally sprinkled throughout the genome of most organisms (Lee et al., 1993). miRNAs share processing steps with siRNA (Kim and Rossi, 2007), but unlike siRNA, a single miRNA regulates a multitude of mRNAs through complete or partial complementarity to sequences contained mostly within $3^{\prime}$ untranslated regions. Ablation of Dicer, the enzyme that cleaves the hairpin loop from a microRNA in a rate-limiting processing step, revealed that an astounding array of miRNA-dependent events control nervous system development, including stem-cell proliferation, cell-type specification, and neural differentiation (Davis et al., 2008; De Pietri Tonelli et al., 2008). And single miRNAs, like miR-124 (Smirnova et al., 2005; Conaco et al., 2006; Visvanathan et al., 2007) or miR-9 (Shibata et al., 2011; Clovis et al., 2012; DajasBailador et al., 2012) display different functions in different cellular contexts. Massive, parallel RNA sequencing (RNA-Seq) has more recently confirmed that siRNAs can be found naturally within the genome and has also helped to identify additional noncoding regulatory RNAs like piRNAs and circular RNAs generated from introns and exons (Chen and Schuman, 2016). This rich network of naturally occurring RNA elements outlines a highly nuanced picture of transcriptional and translational control. Significantly, many noncoding RNAs are more enriched in brain, contained within genes encoding synapse proteins, and are regulated by synapse activity (Cohen et al., 2011; Fiore et al., 2011). Coupled with data showing that nearly half of all long, noncoding (lnc) RNAs are expressed in brain (Mercer et al., 2008) and that miRNA and lncRNA diversity and number appear to have increased dramatically during the evolution of primate brains (Heimberg et al., 2008; Kosik and Nowakowski, 2018), it is clear that it will be of critical importance to understand the mo- 
lecular mechanisms controlling their collective actions (Weiss et al., 2015; Kosik and Nowakowski, 2018).

Current molecular approaches are dominated by unbiased strategies that serve to outline the limits of possibility. A regional or even cell-type-specific transcriptome can be used to identify regulatory RNA elements and the set of mRNAs that have the potential to be translated, and a connectome typically uses molecular tools to pinpoint brain areas or individual neurons that are interconnected. Cell-type-specific expression of ribosome tags (RiboTag and TRAP) can be used to further reduce complexity by permitting the identification of mRNAs that are loaded onto ribosomes and thus are most likely to be translated (Heiman et al., 2008; Sanz et al., 2013). However, all of these strategies stop short of indicating what particular molecules do or the sites within cells in which they act. Recent advances coupling fractionation (Zivraj et al., 2010; Poulopoulos et al., 2019) or the use of intact sections with RNA-Seq (Rodriques et al., 2019) are starting to bridge this information gap.

Single-molecule manipulations have received a major boost by the discovery of CRISPR-Cas9. Like PCR was to the mass adaptation of sequence identification, CRISPR-Cas9 is to sequence manipulation in vivo. Discovered as a viral defense mechanism (Jinek et al., 2012), Cas9 (or its relatives) can be targeted with a single guide RNA in eukaryotes to generate site-specific DNA breaks (Mali et al., 2013; Hsu et al., 2014). Although still in its infancy, the ease of its application has already enabled phenotype-based screens in human cells (Koike-Yusa et al., 2014; Wang et al., 2014; Zhou et al., 2014); and targeted manipulations in terminally differentiated cells (Platt et al., 2014). Coupled with cell-type-specific inducible promoters, the strategy enables experiments in vivo that used to be practical only ex vivo. Like siRNA, widespread use is revealing some unwanted consequences (Zhang et al., 2015), but the use of CRISPR-based strategies as a molecular tool cannot be understated. As it brings within reach the possibility of corrective therapy for certain genetic diseases, its potential for healing is tantalizing, but the possibility of irreparable damage and unknown negative effects will hopefully keep this application at arm's length for the near future.

Currently, investigations of molecular function and molecular assemblies are on the upswing. Enormous progress has been made over the last decade identifying neural circuits driving particular behaviors. Such studies have often been merged with gene and protein expression data to reveal collections of molecules that are coordinately regulated in identified cells and networks in the context of a behavior or in response to pathology. However, many of the molecules identified have unknown or poorly characterized functions. Recent technical advances in labeling strategies, microscopy, and gene manipulation have provided the field with unparalleled opportunities to identify and characterize the function of key molecules and molecular machines, to determine when and where they act, and to assess their actions in vivo. These data are essential for moving the field forward, for understanding how the actions of molecules drive and change behavior, as well as for providing a substrate for understanding the consequences of gene modifications associated with human disease.

\section{References}

Aakalu G, Smith WB, Nguyen N, Jiang C, Schuman EM (2001) Dynamic visualization of local protein synthesis in hippocampal neurons. Neuron 30:489-502.

Altman-Hamamdzic S, Groseclose C, Ma JX, Hamamdzic D, Vrindavanam NS, Middaugh LD, Parratto NP, Sallee FR (1997) Expression of betagalactosidase in mouse brain: utilization of a novel nonreplicative sindbis virus vector as a neuronal gene delivery system. Gene Ther 4:815-822.
Bai J, Ramos RL, Ackman JB, Thomas AM, Lee RV, LoTurco JJ (2003) RNAi reveals doublecortin is required for radial migration in rat neocortex. Nat Neurosci 6:1277-1283.

Baltimore D, Berg P, Botchan M, Carroll D, Charo RA, Church G, Corn JE, Daley GQ, Doudna JA, Fenner M, Greely HT, Jinek M, Martin GS, Penhoet E, Puck J, Sternberg SH, Weissman JS, Yamamoto KR (2015) Biotechnology: a prudent path forward for genomic engineering and germline gene modification. Science 348:36-38.

Bassell GJ, Zhang H, Byrd AL, Femino AM, Singer RH, Taneja KL, Lifshitz LM, Herman IM, Kosik KS (1998) Sorting of beta-actin mRNA and protein to neurites and growth cones in culture. J Neurosci 18:251-265.

Benson DL, Gall CM, Isackson PJ (1992) Dendritic localization of type II calcium calmodulin-dependent protein kinase mRNA in normal and reinnervated rat hippocampus. Neuroscience 46:851-857.

Berg P, Baltimore D, Brenner S, Roblin RO, Singer MF (1975) Summary statement of the asilomar conference on recombinant DNA molecules. Proc Natl Acad Sci U S A 72:1981-1984.

Biederer T, Sara Y, Mozhayeva M, Atasoy D, Liu X, Kavalali ET, Südhof TC (2002) SynCAM, a synaptic adhesion molecule that drives synapse assembly. Science 297:1525-1531.

Biederer T, Kaeser PS, Blanpied TA (2017) Transcellular nanoalignment of synaptic function. Neuron 96:680-696.

Blasi J, Chapman ER, Yamasaki S, Binz T, Niemann H, Jahn R (1993a) Botulinum neurotoxin $\mathrm{C} 1$ blocks neurotransmitter release by means of cleaving HPC-1/syntaxin. EMBO J 12:4821-4828.

Blasi J, Chapman ER, Link E, Binz T, Yamasaki S, De Camilli P, Südhof TC, Niemann H, Jahn R (1993b) Botulinum neurotoxin A selectively cleaves the synaptic protein SNAP-25. Nature 365:160-163.

Brose N, Petrenko AG, Südhof TC, Jahn R (1992) Synaptotagmin: a calcium sensor on the synaptic vesicle surface. Science 256:1021-1025.

Burgin KE, Waxham MN, Rickling S, Westgate SA, Mobley WC, Kelly PT (1990) In situ hybridization histochemistry of $\mathrm{Ca}^{2+} /$ calmodulindependent protein kinase in developing rat brain. J Neurosci 10:17881798.

Campbell DS, Holt CE (2001) Chemotropic responses of retinal growth cones mediated by rapid local protein synthesis and degradation. Neuron 32:1013-1026.

Chalfie M, Tu Y, Euskirchen G, Ward WW, Prasher DC (1994) Green fluorescent protein as a marker for gene expression. Science 263:802-805.

Chamma I, Letellier M, Butler C, Tessier B, Lim KH, Gauthereau I, Choquet D, Sibarita JB, Park S, Sainlos M, Thoumine O (2016) Mapping the dynamics and nanoscale organization of synaptic adhesion proteins using monomeric streptavidin. Nat Commun 7:10773.

Chan KY, Jang MJ, Yoo BB, Greenbaum A, Ravi N, Wu WL, SánchezGuardado L, Lois C, Mazmanian SK, Deverman BE, Gradinaru V (2017) Engineered AAVs for efficient noninvasive gene delivery to the central and peripheral nervous systems. Nat Neurosci 20:1172-1179.

Chen F, Tillberg PW, Boyden ES (2015) Optical imaging: expansion microscopy. Science 347:543-548.

Chen KH, Boettiger AN, Moffitt JR, Wang S, Zhuang X (2015) RNA imaging: spatially resolved, highly multiplexed RNA profiling in single cells. Science 348:aaa6090.

Chen W, Schuman E (2016) Circular RNAs in brain and other tissues: a functional enigma. Trends Neurosci 39:597-604.

Cho KO, Hunt CA, Kennedy MB (1992) The rat brain postsynaptic density fraction contains a homolog of the Drosophila discs-large tumor suppressor protein. Neuron 9:929-942.

Choi VW, McCarty DM, Samulski RJ (2005) AAV hybrid serotypes: improved vectors for gene delivery. Curr Gene Ther 5:299-310.

Chozinski TJ, Halpern AR, Okawa H, Kim HJ, Tremel GJ, Wong RO, Vaughan JC (2016) Expansion microscopy with conventional antibodies and fluorescent proteins. Nat Methods 13:485-488.

Clary DO, Griff IC, Rothman JE (1990) SNAPs, a family of NSF attachment proteins involved in intracellular membrane fusion in animals and yeast. Cell 61:709-721.

Clovis YM, Enard W, Marinaro F, Huttner WB, De Pietri Tonelli D (2012) Convergent repression of Foxp2 3'UTR by miR-9 and miR-132 in embryonic mouse neocortex:implications for radial migration of neurons. Development 139:3332-3342.

Cohen JE, Lee PR, Chen S, Li W, Fields RD (2011) MicroRNA regulation of homeostatic synaptic plasticity. Proc Natl Acad Sci U S A 108:1165011655. 
Cohen SN, Chang AC, Boyer HW, Helling RB (1973) Construction of biologically functional bacterial plasmids in vitro. Proc Natl Acad Sci U S A 70:3240-3244.

Conaco C, Otto S, Han JJ, Mandel G (2006) Reciprocal actions of REST and a microRNA promote neuronal identity. Proc Natl Acad Sci U S A 103:2422-2427.

Cucchiarini M, Ren XL, Perides G, Terwilliger EF (2003) Selective gene expression in brain microglia mediated via adeno-associated virus type 2 and type 5 vectors. Gene Ther 10:657-667.

Dajas-Bailador F, Bonev B, Garcez P, Stanley P, Guillemot F, Papalopulu N (2012) microRNA-9 regulates axon extension and branching by targeting Map1b in mouse cortical neurons. Nat Neurosci 15:697-699.

Dani A, Huang B, Bergan J, Dulac C, Zhuang X (2010) Superresolution imaging of chemical synapses in the brain. Neuron 68:843-856.

Davis RL, Davidson N (1984) Isolation of the Drosophila melanogaster dunce chromosomal region and recombinational mapping of dunce sequences with restriction site polymorphisms as genetic markers. Mol Cell Biol 4:358-367.

Davis TH, Cuellar TL, Koch SM, Barker AJ, Harfe BD, McManus MT, Ullian EM (2008) Conditional loss of dicer disrupts cellular and tissue morphogenesis in the cortex and hippocampus. J Neurosci 28:4322-4330.

De Pietri Tonelli D, Pulvers JN, Haffner C, Murchison EP, Hannon GJ, Huttner WB (2008) miRNAs are essential for survival and differentiation of newborn neurons but not for expansion of neural progenitors during early neurogenesis in the mouse embryonic neocortex. Development 135: 3911-3921.

D’Este E, Kamin D, Göttfert F, El-Hady A, Hell SW (2015) STED nanoscopy reveals the ubiquity of subcortical cytoskeleton periodicity in living neurons. Cell Rep 10:1246-1251.

Doe CQ, Hiromi Y, Gehring WJ, Goodman CS (1988) Expression and function of the segmentation gene fushi tarazu during Drosophila neurogenesis. Science 239:170-175.

Doetschman T, Gregg RG, Maeda N, Hooper ML, Melton DW, Thompson S, Smithies O (1987) Targetted correction of a mutant HPRT gene in mouse embryonic stem cells. Nature 330:576-578.

Elegheert J, Kakegawa W, Clay JE, Shanks NF, Behiels E, Matsuda K, Kohda K, Miura E, Rossmann M, Mitakidis N, Motohashi J, Chang VT, Siebold C, Greger IH, Nakagawa T, Yuzaki M, Aricescu AR (2016) Structural basis for integration of GluD receptors within synaptic organizer complexes. Science 353:295-299.

Fan G, Baker MR, Wang Z, Seryshev AB, Ludtke SJ, Baker ML, Serysheva II (2018) Cryo-EM reveals ligand induced allostery underlying InsP3R channel gating. Cell Res 28:1158-1170.

Felgner PL, Gadek TR, Holm M, Roman R, Chan HW, Wenz M, Northrop JP, Ringold GM, Danielsen M (1987) Lipofection: a highly efficient, lipidmediated DNA-transfection procedure. Proc Natl Acad Sci U S A 84: 7413-7417.

Fernández-Busnadiego R, Zuber B, Maurer UE, Cyrklaff M, Baumeister W, Lucic V (2010) Quantitative analysis of the native presynaptic cytomatrix by cryoelectron tomography. J Cell Biol 188:145-156.

Finney M, Ruvkun G, Horvitz HR (1988) The C. elegans cell lineage and differentiation gene unc-86 encodes a protein with a homeodomain and extended similarity to transcription factors. Cell 55:757-769.

Fiore R, Khudayberdiev S, Saba R, Schratt G (2011) MicroRNA function in the nervous system. Prog Mol Biol Transl Sci 102:47-100.

Fire A, Xu S, Montgomery MK, Kostas SA, Driver SE, Mello CC (1998) Potent and specific genetic interference by double-stranded RNA in Caenorhabditis elegans. Nature 391:806-811.

Fremeau RT Jr, Lundblad JR, Pritchett DB, Wilcox JN, Roberts JL (1986) Regulation of pro-opiomelanocortin gene transcription in individual cell nuclei. Science 234:1265-1269.

Gagliardini V, Fernandez PA, Lee RK, Drexler HC, Rotello RJ, Fishman MC, Yuan J (1994) Prevention of vertebrate neuronal death by the crmA gene. Science 263:826-828.

Gall CM, Isackson PJ (1989) Limbic seizures increase neuronal production of messenger RNA for nerve growth factor. Science 245:758-761.

Ganguly A, Tang Y, Wang L, Ladt K, Loi J, Dargent B, Leterrier C, Roy S (2015) A dynamic formin-dependent deep F-actin network in axons. J Cell Biol 210:401-417.

Gantier MP, Williams BR (2007) The response of mammalian cells to double-stranded RNA. Cytokine Growth Factor Rev 18:363-371.
Garner CC, Nash J, Huganir RL (2000) PDZ domains in synapse assembly and signalling. Trends Cell Biol 10:274-280.

Geller AI, Freese A (1990) Infection of cultured central nervous system neurons with a defective herpes simplex virus 1 vector results in stable expression of escherichia coli beta-galactosidase. Proc Natl Acad Sci U S A 87:1149-1153.

Giraudat J, Devillers-Thiery A, Auffray C, Rougeon F, Changeux JP (1982) Identification of a cDNA clone coding for the acetylcholine binding subunit of torpedo marmorata acetylcholine receptor. EMBO J 1:713-717.

Goeddel DV, Kleid DG, Bolivar F, Heyneker HL, Yansura DG, Crea R, Hirose T, Kraszewski A, Itakura K, Riggs A (1979a) Expression in Escherichia coli of chemically synthesized genes for human insulin. Proc Natl Acad Sci USA 76: 106-110.

Goeddel DV, Heyneker HL, Hozumi T, Arentzen R, Itakura K, Yansura DG, Ross MJ, Miozzari G, Crea R, Seeburg PH (1979b) Direct expression in Escherichia coli of a DNA sequence coding for human growth hormone. Nature 281: 544-548.

Hafner AS, Donlin-Asp PG, Leitch B, Herzog E, Schuman EM (2019) Local protein synthesis is a ubiquitous feature of neuronal pre- and postsynaptic compartments. Science 364:eaau3644.

Hamilton B, Dong Y, Shindo M, Liu W, Odell I, Ruvkun G, Lee SS (2005) A systematic RNAi screen for longevity genes in C. elegans. Genes Dev 19: $1544-1555$.

Hartshorne RP, Catterall WA (1984) The sodium channel from rat brain. purification and subunit composition. J Biol Chem 259:1667-1675.

Hata Y, Slaughter CA, Südhof TC (1993) Synaptic vesicle fusion complex contains unc-18 homologue bound to syntaxin. Nature 366:347-351.

He J, Zhou R, Wu Z, Carrasco MA, Kurshan PT, Farley JE, Simon DJ, Wang G, Han B, Hao J, Heller E, Freeman MR, Shen K, Maniatis T, TessierLavigne M, Zhuang X (2016) Prevalent presence of periodic actinspectrin-based membrane skeleton in a broad range of neuronal cell types and animal species. Proc Natl Acad Sci U S A 113:6029-6034.

Heiman M, Schaefer A, Gong S, Peterson JD, Day M, Ramsey KE, SuárezFariñas M, Schwarz C, Stephan DA, Surmeier DJ, Greengard P, Heintz N (2008) A translational profiling approach for the molecular characterization of CNS cell types. Cell 135:738-748.

Heim R, Tsien RY (1996) Engineering green fluorescent protein for improved brightness, longer wavelengths and fluorescence resonance energy transfer. Curr Biol 6:178-182.

Heimberg AM, Sempere LF, Moy VN, Donoghue PC, Peterson KJ (2008) MicroRNAs and the advent of vertebrate morphological complexity. Proc Natl Acad Sci U S A 105:2946-2950.

Hruska M, Henderson N, Le Marchand SJ, Jafri H, Dalva MB (2018) Synaptic nanomodules underlie the organization and plasticity of spine synapses. Nat Neurosci 21:671-682.

Hsu PD, Lander ES, Zhang F (2014) Development and applications of CRISPR-Cas9 for genome engineering. Cell 157:1262-1278.

Isackson PJ, Huntsman MM, Murray KD, Gall CM (1991) BDNF mRNA expression is increased in adult rat forebrain after limbic seizures: temporal patterns of induction distinct from NGF. Neuron 6:937-948.

Itakura K, Hirose T, Crea R, Riggs AD, Heyneker HL, Bolivar F, Boyer HW (1977) Expression in Escherichia coli of a chemically synthesized gene for the hormone somatostatin. Science 198:1056-1063.

Jackson DA, Symons RH, Berg P (1972) Biochemical method for inserting new genetic information into DNA of simian virus 40: circular SV40 DNA molecules containing lambda phage genes and the galactose operon of escherichia coli. Proc Natl Acad Sci U S A 69:2904-2909.

Jareb M, Banker G (1998) The polarized sorting of membrane proteins expressed in cultured hippocampal neurons using viral vectors. Neuron 20:855-867.

Jinek M, Chylinski K, Fonfara I, Hauer M, Doudna JA, Charpentier E (2012) A programmable dual-RNA-guided DNA endonuclease in adaptive bacterial immunity. Science 337:816-821.

Jordan BA, Fernholz BD, Boussac M, Xu C, Grigorean G, Ziff EB, Neubert TA (2004) Identification and verification of novel rodent postsynaptic density proteins. Mol Cell Proteomics 3:857-871.

Kaiser CA, Schekman R (1990) Distinct sets of SEC genes govern transport vesicle formation and fusion early in the secretory pathway. Cell 61:723733.

Kaplitt MG, Leone P, Samulski RJ, Xiao X, Pfaff DW, O’Malley KL, During MJ (1994) Long-term gene expression and phenotypic correction using 
adeno-associated virus vectors in the mammalian brain. Nat Genet 8:148-154.

Keinänen K, Wisden W, Sommer B, Werner P, Herb A, Verdoorn TA, Sakmann B, Seeburg PH (1990) A family of AMPA-selective glutamate receptors. Science 249:556-560.

Kennedy MB (1995) Origin of PDZ (DHR, GLGF) domains. Trends Biochem Sci 20:350.

Kim DH, Rossi JJ (2007) Strategies for silencing human disease using RNA interference. Nat Rev Genetics 8:173-184.

Kim E, Sheng M (2004) PDZ domain proteins of synapses. Nat Rev Neurosci 5:771-781.

Kistner U, Wenzel BM, Veh RW, Cases-Langhoff C, Garner AM, Appeltauer U, Voss B, Gundelfinger ED, Garner CC (1993) SAP90, a rat presynaptic protein related to the product of the Drosophila tumor suppressor gene dlg-A. J Biol Chem 268:4580-4583.

Koike-Yusa H, Li Y, Tan EP, Velasco-Herrera Mdel C, Yusa K (2014) Genome-wide recessive genetic screening in mammalian cells with a lentiviral CRISPR-guide RNA library. Nat Biotechnol 32:267-273.

Kosik KS, Nowakowski T (2018) Evolution of new miRNAs and cerebrocortical development. Ann Rev Neurosci 41:119-137.

Laverty D, Desai R, Uchański T, Masiulis S, Stec WJ, Malinauskas T, Zivanov J, Pardon E, Steyaert J, Miller KW, Aricescu AR (2019) Cryo-EM structure of the human alphalbeta3gamma2 GABAA receptor in a lipid bilayer. Nature 565:516-520.

Lechan RM, Wu P, Jackson IM, Wolf H, Cooperman S, Mandel G, Goodman RH (1986) Thyrotropin-releasing hormone precursor: characterization in rat brain. Science 231:159-161.

Lee RC, Feinbaum RL, Ambros V (1993) The C. elegans heterochronic gene lin-4 encodes small RNAs with antisense complementarity to lin-14. Cell 75:843-854.

Lein ES, Hawrylycz MJ, Ao N, Ayres M, Bensinger A, Bernard A, Boe AF, Boguski MS, Brockway KS, Byrnes EJ, Chen L, Chen L, Chen TM, Chin MC, Chong J, Crook BE, Czaplinska A, Dang CN, Datta S, Dee NR, et al. (2007) Genome-wide atlas of gene expression in the adult mouse brain. Nature 445:168-176.

Liao M, Cao E, Julius D, Cheng Y (2013) Structure of the TRPV1 ion channel determined by electron cryo-microscopy. Nature 504:107-112.

Lo DC (2001) Neuronal transfection using particle-mediated gene transfer. Curr Protoc Neurosci Chapter 3:Unit 3.15.

Loh KH, Stawski PS, Draycott AS, Udeshi ND, Lehrman EK, Wilton DK, Svinkina T, Deerinck TJ, Ellisman MH, Stevens B, Carr SA, Ting AY (2016) Proteomic analysis of unbounded cellular compartments: synaptic clefts. Cell 166:1295-1307.e21.

Lovett-Barron M, Andalman AS, Allen WE, Vesuna S, Kauvar I, Burns VM, Deisseroth K (2017) Ancestral circuits for the coordinated modulation of brain state. Cell 171:1411-1423.e17.

Macosko EZ, Basu A, Satija R, Nemesh J, Shekhar K, Goldman M, Tirosh I, Bialas AR, Kamitaki N, Martersteck EM, Trombetta JJ, Weitz DA, Sanes JR, Shalek AK, Regev A, McCarroll SA (2015) Highly parallel genomewide expression profiling of individual cells using nanoliter droplets. Cell 161:1202-1214.

Malhotra V, Orci L, Glick BS, Block MR, Rothman JE (1988) Role of an $\mathrm{N}$-ethylmaleimide-sensitive transport component in promoting fusion of transport vesicles with cisternae of the Golgi stack. Cell 54: 221-227.

Mali P, Yang L, Esvelt KM, Aach J, Guell M, DiCarlo JE, Norville JE, Church GM (2013) RNA-guided human genome engineering via Cas9. Science 339:823-826.

Meissner GW, Nern A, Singer RH, Wong AM, Malkesman O, Long X (2019) Mapping neurotransmitter identity in the whole-mount Drosophila brain using multiplex high-throughput fluorescence in situ hybridization. Genetics 211:473-482.

Mercer TR, Dinger ME, Sunkin SM, Mehler MF, Mattick JS (2008) Specific expression of long noncoding RNAs in the mouse brain. Proc Natl Acad Sci U S A 105:716-721.

Miledi R, Parker I, Sumikawa K (1982) Properties of acetylcholine receptors translated by cat muscle mRNA in Xenopus oocytes. EMBO J 1:13071312.

Miller JA, Ding SL, Sunkin SM, Smith KA, Ng L, Szafer A, Ebbert A, Riley ZL, Royall JJ, Aiona K, Arnold JM, Bennet C, Bertagnolli D, Brouner K, Butler S, Caldejon S, Carey A, Cuhaciyan C, Dalley RA, Dee N, et al. (2014) Transcriptional landscape of the prenatal human brain. Nature 508:199206.
Mitra RD, Silva CM, Youvan DC (1996) Fluorescence resonance energy transfer between blue-emitting and red-shifted excitation derivatives of the green fluorescent protein. Gene 173:13-17.

Moffitt JR, Hao J, Bambah-Mukku D, Lu T, Dulac C, Zhuang X (2016) High-performance multiplexed fluorescence in situ hybridization in culture and tissue with matrix imprinting and clearing. Proc Natl Acad Sci U S A 113:14456-14461.

Monyer H, Burnashev N, Laurie DJ, Sakmann B, Seeburg PH (1994) Developmental and regional expression in the rat brain and functional properites of four NMDA receptors. Neuron 12:529-540.

Morgan JI, Cohen DR, Hempstead JL, Curran T (1987) Mapping patterns of c-Fos expression in the central nervous system after seizure. Science 237:192-197.

Moriyoshi K, Richards LJ, Akazawa C, O’Leary DD, Nakanishi S (1996) Labeling neural cells using adenoviral gene transfer of membrane-targeted GFP. Neuron 16:255-260.

Mullis K, Faloona F, Scharf S, Saiki R, Horn G, Erlich H (1986) Specific enzymatic amplification of DNA in vitro: the polymerase chain reaction. Cold Spring Harbor Symp Quant Biol 51:263-273.

Muramatsu T, Mizutani Y, Ohmori Y, Okumura J (1997) Comparison of three nonviral transfection methods for foreign gene expression in early chicken embryos in ovo. Biochem Biophys Res Commun 230:376-380.

Nakai J, Ohkura M, Imoto K (2001) A high signal-to-noise $\mathrm{Ca}\left({ }^{2+}\right)$ probe composed of a single green fluorescent protein. Nat Biotechnol 19:137141.

Naldini L, Blömer U, Gallay P, Ory D, Mulligan R, Gage FH, Verma IM, Trono D (1996) In vivo gene delivery and stable transduction of nondividing cells by a lentiviral vector. Science 272:263-267.

Niethammer M, Kim E, Sheng M (1996) Interaction between the C terminus of NMDA receptor subunits and multiple members of the PSD-95 family of membrane-associated guanylate kinases. J Neurosci 16:21572163.

Nishiyama J, Mikuni T, Yasuda R (2017) Virus-mediated genome editing via homology-directed repair in mitotic and postmitotic cells in mammalian brain. Neuron 96:755-768.e5.

Noda M, Takahashi H, Tanabe T, Toyosato M, Furutani Y, Hirose T, Asai M, Inayama S, Miyata T, Numa S (1982) Primary structure of alphasubunit precursor of torpedo californica acetylcholine receptor deduced from cDNA sequence. Nature 299:793-797.

Noda M, Ikeda T, Suzuki H, Takeshima H, Takahashi T, Kuno M, Numa S (1986) Expression of functional sodium channels from cloned cDNA. Nature 322:826-828.

Novina CD, Sharp PA (2004) The RNAi revolution. Nature 430:161-164.

Pardue ML, Gall JG (1969) Molecular hybridization of radioactive DNA to the DNA of cytological preparations. Proc Natl Acad Sci U S A 64:600604.

Patrick J, Ballivet M, Boas L, Claudio T, Forrest J, Ingraham H, Mason P, Stengelin S, Ueno S, Heinemann S (1983) Molecular cloning of the acetylcholine receptor. Cold Spring Harbor Symp Quant Biol 48:71-78.

Pekarik V, Bourikas D, Miglino N, Joset P, Preiswerk S, Stoeckli ET (2003) Screening for gene function in chicken embryo using RNAi and electroporation. Nat Biotechnol 21:93-96.

Peng J, Kim MJ, Cheng D, Duong DM, Gygi SP, Sheng M (2004) Semiquantitative proteomic analysis of rat forebrain postsynaptic density fractions by mass spectrometry. J Biol Chem 279:21003-21011.

Perez de Arce K, Schrod N, Metzbower SWR, Allgeyer E, Kong GK, Tang AH, Krupp AJ, Stein V, Liu X, Bewersdorf J, Blanpied TA, Lucić V, Biederer T (2015) Topographic mapping of the synaptic cleft into adhesive nanodomains. Neuron 88:1165-1172.

Perin MS, Johnston PA, Ozcelik T, Jahn R, Francke U, Südhof TC (1991) Structural and functional conservation of synaptotagmin (p65) in Drosophila and humans. J Biol Chem 266:615-622.

Phillips GR, Florens L, Tanaka H, Khaing ZZ, Fidler L, Yates JR 3rd, Colman DR (2005) Proteomic comparison of two fractions derived from the transsynaptic scaffold. J Neurosci Res 81:762-775.

Platt RJ, Chen S, Zhou Y, Yim MJ, Swiech L, Kempton HR, Dahlman JE, Parnas O, Eisenhaure TM, Jovanovic M, Graham DB, Jhunjhunwala S, Heidenreich M, Xavier RJ, Langer R, Anderson DG, Hacohen N, Regev A, Feng G, Sharp PA, et al. (2014) CRISPR-Cas9 knockin mice for genome editing and cancer modeling. Cell 159:440-455.

Poulopoulos A, Murphy AJ, Ozkan A, Davis P, Hatch J, Kirchner R, Macklis 
JD (2019) Subcellular transcriptomes and proteomes of developing axon projections in the cerebral cortex. Nature 565:356-360.

Powell SK, Khan N, Parker CL, Samulski RJ, Matsushima G, Gray SJ, McCown TJ (2016) Characterization of a novel adeno-associated viral vector with preferential oligodendrocyte tropism. Gene Ther 23:807-814.

Rodriguez EA, Campbell RE, Lin JY, Lin MZ, Miyawaki A, Palmer AE, Shu X, Zhang J, Tsien RY (2017) The growing and glowing toolbox of fluorescent and photoactive proteins. Trends Biochem Sci 42:111-129.

Rodriques SG, Stickels RR, Goeva A, Martin CA, Murray E, Vanderburg CR, Welch J, Chen LM, Chen F, Macosko EZ (2019) Slide-seq: a scalable technology for measuring genome-wide expression at high spatial resolution. Science 363:1463-1467.

Rosario AM, Cruz PE, Ceballos-Diaz C, Strickland MR, Siemienski Z, Pardo M, Schob KL, Li A, Aslanidi GV, Srivastava A, Golde TE, Chakrabarty P (2016) Microglia-specific targeting by novel capsid-modified AAV6 vectors. Mol Ther Methods Clin Dev 3:16026.

Saiki RK, Scharf S, Faloona F, Mullis KB, Horn GT, Erlich HA, Arnheim N (1985) Enzymatic amplification of beta-globin genomic sequences and restriction site analysis for diagnosis of sickle cell anemia. Science 230: $1350-1354$.

Sanz E, Evanoff R, Quintana A, Evans E, Miller JA, Ko C, Amieux PS, Griswold MD, McKnight GS (2013) RiboTag analysis of actively translated mRNAs in sertoli and leydig cells in vivo. PLoS One 8:e66179.

Scheiffele P, Fan J, Choih J, Fetter R, Serafini T (2000) Neuroligin expressed in nonneuronal cells triggers presynaptic development in contacting axons. Cell 101:657-669.

Schiavo G, Benfenati F, Poulain B, Rossetto O, Polverino de Laureto P, DasGupta BR, Montecucco C (1992) Tetanus and botulinum-B neurotoxins block neurotransmitter release by proteolytic cleavage of synaptobrevin. Nature 359:832-835.

Seabold GK, Wang PY, Chang K, Wang CY, Wang YX, Petralia RS, Wenthold RJ (2008) The SALM family of adhesion-like molecules forms heteromeric and homomeric complexes. J Biol Chem 283:8395-8405.

Shen H, Li Z, Jiang Y, Pan X, Wu J, Cristofori-Armstrong B, Smith JJ, Chin YKY, Lei J, Zhou Q, King GF, Yan N (2018) Structural basis for the modulation of voltage-gated sodium channels by animal toxins. Science 362:eaau2596

Shibata M, Nakao H, Kiyonari H, Abe T, Aizawa S (2011) Micro-RNA-9 regulates neurogenesis in mouse telencephalon by targeting multiple transcription factors. J Neurosci 31:3407-3422.

Siddiqui TJ, Pancaroglu R, Kang Y, Rooyakkers A, Craig AM (2010) LRRTMs and neuroligins bind neurexins with a differential code to cooperate in glutamate synapse development. J Neurosci 30:7495-7506.

Siegel MS, Isacoff EY (1997) A genetically encoded optical probe of membrane voltage. Neuron 19:735-741.

Smirnova L, Gräfe A, Seiler A, Schumacher S, Nitsch R, Wulczyn FG (2005) Regulation of miRNA expression during neural cell specification. Eur J Neurosci 21:1469-1477.

Songyang Z, Fanning AS, Fu C, Xu J, Marfatia SM, Chishti AH, Crompton A, Chan AC, Anderson JM, Cantley LC (1997) Recognition of unique carboxyl-terminal motifs by distinct PDZ domains. Science 275:73-77.

Spence EF, Dube S, Uezu A, Locke M, Soderblom EJ, Soderling SH (2019) In vivo proximity proteomics of nascent synapses reveals a novel regulator of cytoskeleton-mediated synaptic maturation. Nat Commun 10:386.

Stowell JN, Craig AM (1999) Axon/dendrite targeting of metabotropic glutamate receptors by their cytoplasmic carboxy-terminal domains [see comments]. Neuron 22:525-536.

Südhof TC, Baumert M, Perin MS, Jahn R (1989) A synaptic vesicle membrane protein is conserved from mammals to Drosophila. Neuron 2:1475-1481.

Tang AH, Chen H, Li TP, Metzbower SR, MacGillavry HD, Blanpied TA (2016) A trans-synaptic nanocolumn aligns neurotransmitter release to receptors. Nature 536:210-214.

Tannahill D, Bray S, Harris WA (1995) A Drosophila E(spl) gene is "neurogenic" in Xenopus: a green fluorescent protein study. Dev Biol 168:694697.

Tao CL, Liu YT, Sun R, Zhang B, Qi L, Shivakoti S, Tian CL, Zhang P, Lau PM, Zhou ZH, Bi GQ (2018) Differentiation and characterization of excitatory and inhibitory synapses by cryo-electron tomography and correlative microscopy. J Neurosci 38:1493-1510.
Thomas KR, Capecchi MR (1987) Site-directed mutagenesis by gene targeting in mouse embryo-derived stem cells. Cell 51:503-512.

Tian L, Hires SA, Mao T, Huber D, Chiappe ME, Chalasani SH, Petreanu L, Akerboom J, McKinney SA, Schreiter ER, Bargmann CI, Jayaraman V, Svoboda K, Looger LL (2009) Imaging neural activity in worms, flies and mice with improved GCaMP calcium indicators. Nat Methods 6:875-881.

Trimble WS, Cowan DM, Scheller RH (1988) VAMP-1: a synaptic vesicleassociated integral membrane protein. Proc Natl Acad Sci U S A 85: $4538-4542$.

Tsien JZ, Chen DF, Gerber D, Tom C, Mercer EH, Anderson DJ, Mayford M, Kandel ER, Tonegawa S (1996) Subregion- and cell type-restricted gene knockout in mouse brain. Cell 87:1317-1326.

Valtschanoff JG, Weinberg RJ (2001) Laminar organization of the NMDA receptor complex within the postsynaptic density. J Neurosci 21:12111217.

Vargas KJ, Schrod N, Davis T, Fernandez-Busnadiego R, Taguchi YV, Laugks U, Lucic V, Chandra SS (2017) Synucleins have multiple effects on presynaptic architecture. Cell Rep 18:161-173.

Visel A, Thaller C, Eichele G (2004) GenePaint.org: an atlas of gene expression patterns in the mouse embryo. Nucleic Acids Res 32:D552-556.

Visvanathan J, Lee S, Lee B, Lee JW, Lee SK (2007) The microRNA miR-124 antagonizes the anti-neural REST/SCP1 pathway during embryonic CNS development. Genes Dev 21:744-749.

Wang C, Zhai X, Zhang X, Li L, Wang J, Liu DP, Chinese Academy of Medical S (2019) Gene-edited babies: Chinese Academy of Medical Sciences' response and action. Lancet 393:25-26.

Wang T, Wei JJ, Sabatini DM, Lander ES (2014) Genetic screens in human cells using the CRISPR-Cas9 system. Science 343:80-84.

Way JC, Chalfie M (1988) mec-3, a homeobox-containing gene that specifies differentiation of the touch receptor neurons in C. elegans. Cell 54:5-16.

Weiss K, Antoniou A, Schratt G (2015) Non-coding mechanisms of local mRNA translation in neuronal dendrites. Eur J Cell Biol 94:363-367.

Wigler M, Silverstein S, Lee LS, Pellicer A, Cheng Yc, Axel R (1977) Transfer of purified herpes virus thymidine kinase gene to cultured mouse cells. Cell 11:223-232.

Woo J, Kwon SK, Choi S, Kim S, Lee JR, Dunah AW, Sheng M, Kim E (2009) Trans-synaptic adhesion between NGL-3 and LAR regulates the formation of excitatory synapses. Nat Neurosci 12:428-437.

Woodward A, Hashikawa T, Maeda M, Kaneko T, Hikishima K, Iriki A, Okano H, Yamaguchi Y (2018) The Brain/MINDS 3D digital marmoset brain atlas. Sci Data 5:180009.

Xia Z, Dudek H, Miranti CK, Greenberg ME (1996) Calcium influx via the NMDA receptor induces immediate early gene transcription by a MAP kinase/ERK-dependent mechanism. J Neurosci 16:5425-5436.

Xu K, Zhong G, Zhuang X (2013) Actin, spectrin, and associated proteins form a periodic cytoskeletal structure in axons. Science 339:452-456.

Yoshimura Y, Yamauchi Y, Shinkawa T, Taoka M, Donai H, Takahashi N, Isobe T, Yamauchi T (2004) Molecular constituents of the postsynaptic density fraction revealed by proteomic analysis using multidimensional liquid chromatography-tandem mass spectrometry. J Neurochem 88:759-768.

Zhang XH, Tee LY, Wang XG, Huang QS, Yang SH (2015) Off-target effects in CRISPR/Cas9-mediated genome engineering. Mol Ther Nucleic Acids 4:e264.

Zhao Y, Chen S, Swensen AC, Qian WJ, Gouaux E (2019) Architecture and subunit arrangement of native AMPA receptors elucidated by cryo-EM. Science 364:355-362.

Zheng JQ, Kelly TK, Chang B, Ryazantsev S, Rajasekaran AK, Martin KC, Twiss JL (2001) A functional role for intra-axonal protein synthesis during axonal regeneration from adult sensory neurons. J Neurosci 21: 9291-9303.

Zhou Y, Zhu S, Cai C, Yuan P, Li C, Huang Y, Wei W (2014) Highthroughput screening of a CRISPR/Cas9 library for functional genomics in human cells. Nature 509:487-491.

Zivraj KH, Tung YC, Piper M, Gumy L, Fawcett JW, Yeo GS, Holt CE (2010) Subcellular profiling reveals distinct and developmentally regulated repertoire of growth cone mRNAs. J Neurosci 30:15464-15478. 